\title{
CANNIBAL CITIES: MONSTROUS URBAN BODIES IN CONTEMPORARY FANTASY
}

\author{
Cidades Canibais: Corpos Urbanos Monstruosos na \\ Fantasia Contemporânea
}

\author{
Elana Gomel (Tel-Aviv University)
}

\begin{abstract}
This paper discusses the literalization of the metaphor of the body politic in contemporary urban fantasy. The body politic is one of the master tropes through which urban experience has been traditionally represented in literature, political discourse, and social studies. Urban fantasy transforms this metaphor into part of the fictional world of the text, thereby laying bare its cultural connotations, which are predominantly negative and dystopian. Thus a monstrous body is created, which is not that of an individual but rather of the city as a whole. The paper discusses three main registers of representing the monstrous urban body in fantasy: the dark city; the city-asmachine; and the city-as-organism. Each register is illustrated with a range of literary and cinematic examples.
\end{abstract}

KEYWORDS: Body politic; Monstrosity; Literalization; Spatial practices; Urban representations; Urban fantasy.

RESUMO: Este estudo discute a literalização da metáfora do corpo político na fantasia urbana contemporânea. O corpo político é um dos principais tropos através dos quais a experiência urbana tem sido tradicionalmente representada na literatura, no discurso político e nos estudos sociais. A fantasia urbana transforma esta metáfora numa parte do mundo ficcional do texto, expondo as suas conotações culturais, as quais são predominantemente negativas e distópicas. Assim, é criado um corpo monstruoso, que não corresponde ao de um indivíduo mas ao da cidade como um todo. Este ensaio discute três principais registos usados para representar o corpo urbano monstruoso na Fantasia: a cidade escura; a cidade como máquina; e a cidade como organismo. Cada um destes registos é ilustrado através de um leque de exemplos literários e cinematográficos.

PALAVRAS-CHAVE: Corpo político; Monstruosidade; Literalização; Prática espacial; Representações do urbano; Fantasia urbana. 


\section{"A deformed giant"}

The analogy between city and body is deeply entrenched in Western culture, going back to the deepest antiquity. Richard Sennett in his classic Flesh and Stone: The Body and the City in Western Civilization describes how "in the course of urban development master images of 'the body' have frequently been used, in a transfigured form, to define what a building or an entire city should look like" (24). The metaphor of the body politic was instrumental in framing representations of the city in the nineteenth-century novel, from the vermin-infested London in Charles Dickens' Bleak House (1853) to the alluring and sexualized Paris in Emile Zola's Nana (1880). The corporeality of the city became the nexus through which social relations were expressed and negotiated.

While the corporeal imagery of the city in the antiquity and the Middle Ages was heroic and emblematic, with the rise of the industrial metropolis, the body of the city became monstrous and distorted. Thomas Hardy saw London as "a monster whose body had four million heads and eight million eyes" (qtd in RAYMOND WILLIAMS, p. 216). The unsettling image of the bleeding city in William Blake's "London" (1794) in which "the hapless Soldiers sigh/ Runs in blood down Palace walls" echoed throughout the Victorian age in the increasingly nightmarish visions of urban sickness and decay. Roger Ackroyd in his monumental London: A Biography (2000) both evokes an older heroic image of the urban body and juxtaposes it with a darker vision of a misshapen and sick metropolis:

Whether we consider London as a young man refreshed and risen from sleep, therefore, or whether we lament its condition as a deformed giant, we must regard it as a human shape with its own laws of life and growth. (ACKROYD, p. 1)

But there are important generic differences in the way the urban body is represented in literature. The most significant of those is the difference between the figurative and the literal, or between realism and fantasy.

Urban fantasy is an extremely popular genre but it is not easy to define. In her broad overview of its roots and development, Sarai Mannolini-Winwood claims that “UF, unlike typical Secondary World narratives, presents a mundane world immersed in supernatural presence". What she means by "the mundane world" is a city, specifically a more or less contemporary metropolis as opposed to the pseudo-medieval 
towns of epic fantasy of the "sword and sorcery" type. Urban fantasy explores the "spatial practices" of contemporary global culture, to use Henri Lefebvre's term for social manipulation of physical space (p. 33). But it does so in a way more radical than realistic or quasi-realistic fiction.

City-as-body in the realistic novel necessarily remains a metaphor, situated on what narratology calls the extradiegetic level of the text: the level of "how" rather than "what".[1] Insofar as the fictional world of, say, Bleak House is concerned, London remains what it is in real life: a conglomerate of inert objects; its dwellings - wood and stone; its streets - mere topographical markers. It is only in the narrator's discourse that the city becomes flesh and blood, as the miserable slum Tom-All-Alone's is metaphorically likened to a maggot-infested corpse:

\footnotetext{
Now, these tumbling tenements contain, by night, a swarm of misery. As on the ruined human wretch vermin parasites appear, so these ruined shelters have bred a crowd of foul existence that crawls in and out of gaps in walls and boards; and coils itself to sleep, in maggot numbers, where the rain drips in... (Bleak House, Chapter xvi)
}

However, in fantasy, a city can actually be a living being in the fictional world of the text. A monstrous city in a fantasy novel is more than a metaphor; it may become a character or an actant. Among literary genres, fantasy has the unique capacity of translating metaphors into components of the fictional world. It does so through the process of literalization. Described by Tzvetan Todorov in his classic The Fantastic, literalization can be defined as projection of rhetorical tropes from the extradiegetic level to the diegetic level of the text or to put it in simpler terms, the fantastic "often appears because we take a figurative sense literally" (TODOROV, p. 77). What is a metaphor in Dickens or Hardy becomes a diegetic characteristic of urban space in fantasy.

The literalization of the city-as-body trope in fantasy enables the author to explore the collective urban experience in a way impossible in realism. Realistic fiction by necessity focuses on the individual, even when such a focus is contrary to its thematic implications. Bleak House is a novel about social systems that constrain the individual. But despite the complexity of the novel's structure and its multitude of characters, Dickens is required by the very exigencies of realism to focus on individual choices and actions. [2]

But in fantasy, a metaphorical body politic may become an actual, physical body that incorporates the bodies of its members. Depending on how this incorporation is represented, fantasy can explore master tropes that structure our urban culture and probe what Sennett calls the "great divide in the imagery of the body politic" between 
those who envision "the city as a space which ranks bodies living together", and those who envision "the city as a space which connects bodies living together" (SENNETT, p. 168; emphasis mine). In other words, the city may be a locus of social solidarity or of social divisiveness; of inclusion or tyranny; of utopia or dystopia. The relationship between the body politic and the individual body in fantasy reflects these conflicting urban discourses.

In this essay I will consider the literalized image of the body politic in urban fantasy as an instance of what Victor Burgin calls "representations of space", or conceptual topologies (BURGIN, p. 27). The specific representation of space I am interested in is the monstrous city. I will discuss three types of the monstrous city in contemporary urban fantasy: the city of darkness; the city as a machine; and the city as a biological entity. I will argue that they represent progressive stages in the development of a single underlying trope: the submergence of the individual in the increasingly complex and ungovernable body politic. Eventually the city becomes a cannibalistic monster that devours its inhabitants.

This seems to indicate that the fantastic city is always dystopian. But in fact, this is not the case. A more nuanced analysis will disclose a deeper ambivalence attached to the urban body politic. After all, the very idea of the monstrous implies a certain kind of transcendence, "the harmonious combination of the grotesque and the sublime" (LEE \& THOMPSON, p. 246). The monstrous city is dangerous, overpowering and contemptuous of the individual. But it is also sublime.

\section{"Darkness Visible"}

It is hard to remember now that for most of human history, cities were literally dark places. Ancient and medieval cities were as much at mercy of the nightfall as the Antarctic wilderness is today. At best, individual householders were sometimes ordered to put candles in their windows at night. There were also torch-bearing watchers and professional "linkmen" for hire. But until the seventeenth century, European cities at night were dark mazes, which one navigated at one's peril. "Each evening, the medieval community prepared itself for dark like a ship's crew preparing to face a gathering storm" (SCHIVELBUSCH, p. 81). No surprise, then, that Hell itself was often envisioned 
as a dark city; in Percy Byshhe Shelley's words, "Hell is a city much like London --/ A populous and a smoky city" [3].

The revolution that brought light into the city had several stages and two main sources. The stages were marked by successive technological innovations: the reflector lantern, gas, electricity, neon. The sources were the concentration of power in the hands of the absolutist state, on the one hand; and the development of commerce, on the other. The first produced the standardized street lanterns introduced in Paris in the late seventeenth century; the second - the brightly lit shop windows that appeared at roughly the same time and eventually evolved into the dazzling shopping arcades and department stores of the late nineteenth century that, in the words of a contemporary observer, created a "labyrinth of iridescent passages, like rainbow bridges in an ocean of night": a maze of light instead of a maze of darkness (qtd in SCHIVELBUSCH, p.152).

The defeat of the night produced - as technological revolutions are wont to do contradictory responses. On the one hand, it spurred the utopians into coming up with more and more radical schemes of total illumination. In 1885 French engineers Sebillot and Bourdais submitted to the committee preparing the 1889 Exhibition the project of building a 360-meters-high Sun Tower to illuminate the whole of Paris and thus banish darkness forever from the streets of the City of Light. The project was supposed to utilize the recently invented electric arc-light, whose spectrum is very close to the spectrum of sunlight. It was narrowly defeated by another monument to the power of technology: the Eiffel Tower. In America municipal lighthouses were actually built, as a number of cities, including Detroit and San Jose, CA, were lit by arc-lamps mounted on towers, from 50 to 150 meters tall that shed uniform light over the entire urban area.

On the other hand, however, the harshness of the perpetual daylight sparked off a nostalgia for the night, manifested in the late Victorian craze for heavy curtains and impenetrable lamp-shades. Robert Louis Stevenson's essay “A Plea for Gas Lamps” (1903) envisions a city of light as a nightmare:

What a spectacle, on some clear, dark nightfall, from the edge of Hampstead Hill, when in a moment, in the twinkling of an eye, the design of the monstrous city flashes into vision - a glittering hieroglyph many square miles in extent; and when, to borrow and debase an image, all the evening street-lamps burst together into song!..... a new sort of urban star now shines out nightly, horrible, unearthly, obnoxious to the human eye; a lamp for a nightmare! Such a light as this should shine only on murders and public crime, or along the corridors of lunatic asylums, a horror to heighten horror. 
Stevenson's "monstrous city" epitomizes the way in which artificial light becomes incorporated into the metaphor of the dark city. Instead of banishing darkness, artificial light made it visible. The popular genre of the noir novel and film presented the modern metropolis as a dark city, in which the harsh illumination of streetlights and neon signs only emphasized the ubiquity of violence, crime and secrecy. In describing the uses of darkness in the Gothic novel, Dani Cavallaro traces the long literary tradition of "dark places [that] are associated with locked rooms which hide not only taboo objects but also unutterable secrets and crimes" (27). Cavallaro goes on to argue that the dark room of the Gothic becomes the dark city of fantasy: "Cities, both ancient and modern, repeatedly stand out as some of the most intriguing of dark places" (32).

The dark city of fantasy is best observed in movies: the noir contrast of darkness and light making for irresistible visuals. Several classic fantasy and science-fiction movies make urban darkness into their main theme: Blade Runner (1982), The Thirteenth Floor (1999), and most importantly, the eponymous The Dark City (1998). I will briefly discuss the three, focusing on the progressive literalization of the trope of the dark city.

The Los Angeles of Blade Runner is not literally plunged into a perpetual night but the iconic shots of the city are all of the gloomy skyscrapers under the starless sky, lit up only by giant ads and signs. Wong Kin Yuen relates the visual aesthetics of the movie to his native city of Hong Kong, arguing that "as in Blade Runner, the most popular model for artists' and filmmakers' dark and sprawling cities of the future is an Asiandominated metropolis" (2). The dark city, then, expresses a complex of geopolitical anxieties related to the rise of China and Japan as economic rivals to the West, along with an insidious racism and fear of the pollution of the urban body politic.

In The Thirteenth Floor, the dark city is a computer simulation, based on the iconic imagery of the classic film noir. Yet, despite its virtuality, the city is suffused with physical violence. Thus, the dark city becomes a locus for the paradox analyzed by Sennett, in which the urban environment undermines the traditional distinction between nature and artifice, body and mechanism. A city is an artificial environment yet it is the one in which the natural human corporeality becomes obvious and inescapable, as people are forced to live in close proximity to each other, constantly exposed to the bodies of strangers. The "replicants" of Blade Runner symbolize this paradox: they are androids, made rather than born, and yet they suffer pain, fear and mortality. Indeed, the whole point of the movie is that there is no difference between "real" humans and their android simulacra. 
A similar point is made even more explicitly in The Dark City, Alex Proyas' stylish 1998 film. The Dark City is a pastiche of several cinematic genres, primarily the film noir and the German Expressionist horror movie. The film's perpetually dark cityscape of a fictional 1940s LA is populated by sinister Nosferatu-like aliens with Sam Spade raincoats and jaunty hats. Like the city in The Thirteenth Floor, the Dark City is a simulation; and like the "replicants" in Blade Runner, it is a simulation which questions the very nature of reality.

The city blurs the boundary between organic and mechanic, natural and artificial. It is a laboratory in which the aliens pursue their agenda of capturing the human "soul" by mixing and falsifying memories. However, the inhabitants of the Dark City have no stable identities that can be salvaged from the chemical cocktail of mixed memories with which they are injected every midnight. Their misremembered life-stories are as fluid as the topography of the city itself, in which the houses stretch and contract to accommodate; the pavements and staircases spring out of nothingness; and doors and windows migrate in accordance with the aliens' routes.

However, while the psyche is malleable, the body remains the one unquestionable reality. The movie insists on the materiality of memory, representing it not as a cognitive process, but as a corporeal experience. The past is remade through its inscription on the body; and the truth of memory derives not from its correspondence to actual events in the past but from the body's immediate experiences of pleasure and pain. These material effects of memory are emphasized through the gross physicality of the injections that create new identities; through the graphic mutilations of the female bodies killed by the serial murderer persona created by the aliens; and through the aliens' own longing for human sensations. The city itself, with its fluid sidewalks, palpitating rooms and tumescent high-rises, becomes a corporeal presence. When at the end of the movie light bursts into the confines of the Dark City, it exposes only more darkness, as the city is revealed to be a station floating in space.

Thus, the literalization of the metaphor of the dark city in fantasy movies explores the ambivalence toward the urban body. On the one hand, the body is seen as vulnerable, exploited, diseased, and polluted. On the other hand, as Sennett argues, the shared corporeality of city dwellers who see themselves as parts of the same body politic, creates the bonds of solidarity, empathy and eventually, collective action. The dark city is a tomb; but it is also a womb, a cradle of new life.

Nowhere does this ambivalence become more explicit than in the topos of the underground. The underground is both one of the most ancient of "representations of 
space" and the most modern. On the one hand, the traditional iconography of Hell locates it deep in the bowels of the Earth. On the other hand, the contemporary industrialized metropolis necessarily has an undercity, composed of sewers; water, gas and electricity mains; service tunnels, and so on. In addition, many cities, such as London, New York, Moscow, Hong Kong, Paris and others, have underground transportation networks that are not only economically indispensable but symbolically charged as well.

The undercity generates fears and anxieties, which find expressions in a cinematic bestiary of urban monsters, subterranean crawlers, and lurkers in the abyss. These fears center on darkness; invisibility; and the unknown. Similar fears often cluster around the insides of our own bodies. And indeed, the analogy between the guts of a city and the guts of a person is almost irresistible. The undercity is the place where energy is circulated and waste is processed and eliminated. Stallybrass and White point out that the underground is often symbolically conflated with the "lower" aspects of human corporeality.

Trench and Hillman open their exploration of subterranean London with an invocation of the organic darkness beneath their feet that combines images of the bodily interior with hints of cave-dwelling past:

As we bask in the electric sunshine of our city surface, we are quite unaware of the subterranean labyrinth honeycombing the ground beneath our feet. Very occasionally, in time of war, strike or flood warning, we become aware of this troglodyte city, London under London...Despite our ignorance, London under London is there, palpable but hidden; without it, life on the surface would become uncomfortable, unhealthy, even deadly. Like the human body, London hides its organisms within it. There are arteries bearing the body's fluids, lungs enabling it to breathe, bones giving it support, muscles endowing it with strength, nerves carrying signals, and bowels disposing wastes. (p. 7)

In a long series of YA fantasy novels entitled Tunnels, Roderick Gordon and Brian Williams explore "the troglodyte city". Penetrating ever so deeper into a vast underground supposedly existing under London, Gordon's and Williams' protagonists find in the subterranean darkness a world of quasi-medieval settlements, giant insects, and deadly diseases. The organic quality of the underground, which is a metaphor in Trench's and Hillman's non-fictional geography of "London under London", becomes the actual property of the fantastic world of Tunnels. The same organic aspect is emphasized in Neil Gaiman's Neverwhere, in which "London Below" is depicted as filthy, 
dangerous, and yet - as opposed to its sterile upper-class counterpart "London Above" - exuberantly alive.

The conflation between the individual body and the body politic runs as the dominant trope through fantasies of the dark city, whether it is located above- or underground. In Stephen Palmer's The Rat and The Serpent, the perpetually dark metropolis, a fantastic equivalent of Byzantium/Constantinople, is encircled by a stupendous dragon whose exhalation is the soot that is keeping the city shrouded in the night. Killing the dragon lets in the light and yet, as in The Dark City, the ending of Palmer's novel is ambiguous. The dark city may be monstrous, threatening, and devouring. On the other hand, being part of the dark body politic means that one is connected to other bodies "living together" (SENNETT, p. 182).

But if organic togetherness is one aspect of the contemporary urban experience, another aspect of it is the sense of mechanical disconnection, of people being no more than interchangeable nuts and bolts within an impersonal mechanism. A seemingly opposite trope to that of the dark city is the one of the urban machine, flooded by the impossibly bright light, with no protective darkness to hide in from the all-seeing eye of surveillance. And yet, even the city-as-machine may come to life.

\section{"Mortal engines"}

In a striking contrast to representations of the underground city as the viscera of a body, Rosalind Williams in Notes on the Underground speaks of the underworld a sterile, cold, mechanical space: "The defining characteristic of the subterranean environment is the exclusion of nature...The subterranean laboratory takes to an extreme the ecological simplification of modern cities..." (p. 20).

Williams draws upon an alternative tropological framework of urban representation: the city as a machine. This is a city depicted in Fritz Lang's classic 1927 movie Metropolis:

Gigantic pyramidal pistons moving slowly up and down./ Wheels turning./ Electrical insulators./Rods and gleaming shafts./Cams and winding gear./The slow-moving cogs of a great machine. (LANG, $\mathrm{p}$. 19)

Just like the dark city, the city-as-machine is an ambivalent metaphor. On the one hand, it expresses the fear of alienation and dehumanization. On the other hand, the Modern Movement in architecture and urban design, made the machine into a symbol 
of a new utopian urbanism. The famous architect and urban theoretician Le Corbusier defined the house (and by extension, the city) as a "machine for living" (The Modulor 28). In Le Corbusier's writings, the perils of urbanity are expressed through "metaphors and images of the city as a sick body", while "his prescriptions [are] always couched in terms of the city as machine" (DONALD, p. 57). The twentieth-century Modern Movement disdained the Victorian "BEAST of the great city", imagining the mechanical city as its utopian counterweight: "all the utopias that were developed at the beginning of the twentieth century said goodbye to the old city" (TIETZ, p. 41).

With the rise of architectural postmodernism in the 1970s, however, the tables were turned. Robert Venturi's manifesto Learning from Las Vegas (1977) emphasized the congruence between individual bodies and architectural environments. Under the influence of phenomenology, architecture began to experiment with projects in which "emphasis on bodily experience... exposed the limits of functional principles" (HALE, p. 124).

Urban fantasy, paradoxically, responds to the architectural opposition of the body and the machine by conflating the two. In other words, what seems to be a dead mechanical artifact is revealed as an organic, or quasi-organic entity. The best example of this is the brilliant series of novels by Philip Reeve that includes Mortal Engines (2001) and its three sequels. The premise of the series is that cities, including London, have become perambulatory mechanical monsters, roaming the world and consuming each other. At the very beginning of the first novel, its young protagonist Tom is musing as he sees a smallish town about to be devoured by London:

The little town was so close that he could see the antlike shapes of people running about on its upper tiers. How frightened they must be, with London bearing down on them and nowhere to hide! But he knew he mustn't feel sorry for them: It was natural that cities ate towns, just as the towns ate smaller towns and smaller towns snapped up the miserable static settlements. This was Municipal Darwinism, and it was the way the world had worked for a thousand years... (p. 10)

"Municipal Darwinism" is a not-so-subtle reference to Social Darwinism as the dominant ideology of neo-liberal market economy. The steampunk aesthetics of the novels references the Victorian metropolis as the archetypal image of the industrial city. What is interesting in Reeve's novels, however, is that his perambulatory conurbations are simultaneously dead and alive; mechanical and organic; machines and bodies. They incarnate Le Corbusier's image of the "Great Beast" of the city but as a mechanical 
simulacrum rather than an actual organism. They are cyborg cities. The title "Mortal Engines" encapsulates the conflation of machine and body that bridges the divide between architectural modernism and postmodernism to create a composite image of an urban monster:

It was bigger than he remembered, and much uglier. Strange how when he'd lived there, he had believed everything the Goggle Screens told him about the city's elegant lines, its perfect beauty. Now he saw that it was ugly - no better than any other town, just bigger: a storm front of smoke and belching chimneys, a wave of darkness... (REEVE, p. 281)

Both city-as-machine and city-as-body may be used as vehicles of social critique, though in subtly different ways. The city-as-machine implies the dehumanization of the workers functioning as so many cogs and wheels in the soulless automaton of capitalist production: the meaning made explicit in the Moloch scene of Metropolis. The city-asbody figures the same dehumanization and exploitation of the poor through the metaphors of predation and incorporation. The first refers to capitalism as production; the second - to capitalism as consumption. Reeve's "infernal devices" (the title of the third book in the series) combine the two. The monstrous city becomes an organic-cummechanical predator, consuming human lives in order to sustain its own activity.

Reeve's series ends with a defeat of cyborg cities; at the conclusion of the last book The Darkling Plain (another Victorian reference, this time to Matthew Arnold's poem), the moving cities have been forgotten in a pastoral world whose inhabitants laugh at the very idea: "cities only moved in fairy tales; who would want to live in a moving city? It was a mad idea" (2006, p. 558). And yet, a city as a mobile, intentional, predatory entity comes back again and again, dominating urban fantasy's literalization of contemporary "spatial practices".

\section{Walking giants}

Both the dark city and the mechanical city literalize aspects of the metaphor of the body politic: the dark city by generating organic spaces filled with hidden, dangerous and alluring life; the city-as-machine by appropriating character attributes, such as mobility and predation. But in some fantasy texts, the process of literalization is taken to its logical extreme: the city is a body.

This transition from figurative to literal occurs in stages. In some works of urban fantasy, an actual city, such as New York or London, becomes infested with magical 
denizens: fairies, monsters, or vampires. This is probably the most common way for an urban setting to be shifted into a fantastic fictional world. The topography of the actual city is largely preserved but it is overlaid with a secret world of magic and danger. This occurs in such fantasy classics as the Harry Potter series; but I am more interested in cases in which the "infested" city is figured as alive. In Holly Black's fantasy Valiant (2006), for example, fairies inhabit the disused tunnels of the New York subway system, which becomes animated due to their presence:

As they walked through the subway tunnel, the failing flashlight washed the black walls amber, highlighting the miles of electrical cording that threaded through the tunnel. It was like moving through the veins of the city. (BLACK, p. 80)

A more extensive move toward the literalization of the city-as-body trope occurs in Tim Lebbon's Toxic City trilogy (London's Eye; Reaper's Legacy; Contagious). The title itself gestures toward the city as an infected, poisoned and suffering body. The premise of the trilogy is that after a viral apocalypse unleashed upon London, its surviving denizens transform into mutants with sundry superpowers. The emphasis upon corporeal metamorphosis "bleeds" from the depiction of the characters to the city itself, as it becomes an organic hell infested with strange and deadly creatures, less and less resembling humanity as we know it.

In another Lebbon's urban fantasy Echo City (2010) the dark underground gives birth to a stupendous monster named the Vex that destroys the city. The Vex is a literalization of the metaphor of the "buried past" that figures prominently in both fictional and non-fictional representations of urban spaces. Echoing Freud's famous description of Rome as composed of layers of history in Civilization and Its Discontents, Lebbon's city represses its collective traumas by exiling them into the underground "Echoes" and building it supposedly bright future on top of the endlessly growing pile of unacknowledged memories. As one character explains:

...the past is a living place. The deeper you go, the further into history you travel. The city doesn't deal with history. It builds over its past, encloses it, shuts it off, and while tradition might persist, the real histories are soon forgotten. It's the present that matters to Echo City... (p. 212)

Of course, this backfires: just like the memories in The Dark City, the past, no matter how repressed, is precisely what gives life to the city. The Vex, a giant terrifying presence that rises from the Echoes, becomes a visible incarnation of the undead power 
of history: “It's history exploding. It's been under pressure for so long, and now it's all coming back...Coming back to haunt us" (p. 428).

In Greg Bear's short story "Blood Music" (1984; eventually expanded into a novel in 1990), the city becomes a nightmare perpetrator of sexual violence:

I dreamed that New York City was raping a woman. By the end of the dream, she was giving birth to little embryo cities, all wrapped up in translucent sacs, soaked with blood from the difficult labor. ("Blood Music", p. 20)

However, probably the most extreme literalization of the body politic is Clive Barker's story "In the Hills, the Cities" (1984). The story presents two warring towns in the hills of former Yugoslavia, the inhabitants of which lash and fuse themselves into two stampeding giants for the greater glory of the community. Each town is "a sexless giant, made of men, and women, and children", "a darkness in the shape of a man, a vast, broad human frame, a colossus that soared up to meet heaven", whose surface, composed of hundreds of bodies, "seethed and swarmed" (BARKER, p. 56):

Popolac was a city and a giant; and it had gone into the hills. Now their eyes were becoming accustomed to the night light. They could see in ever more horrible detail the way this monster was constructed. It was a masterpiece of human engineering: a man made entirely of men. Or rather, a sexless giant, made of men and women and children. All the citizens of Popolac writhed and strained in the body of this fleshknitted giant, their muscles stretched to breaking point, their bones close to snapping [...] The bodies that were bound together to make its surface were naked but for their harnesses, so that its surface glistened in the starlight, like one vast human torso [...]. They could see the way the roped bodies pushed and pulled against each other in solid cords of flesh and bone. (BARKER, p. 59)

When the horrified Englishman asks a local why the townspeople willingly torture themselves into these unspeakable forms, he replies: "It is the body of the state [...] it is the shape of our lives" (p. 57). Considering when the story was written, the political implications are unmistakable: the totalitarian state is imaged as a monstrous body politic, a literal Leviathan consuming the individual lives of its constituents. Nevertheless, the genuinely horrifying impact of the story comes from the mangled flesh and spilled blood of the city, which is not merely a striking metaphor but an actual character.

Yet, the stampeding giant of the body politic is not only destructive but also sublime. The two Englishmen succumb to its irresistible power, willingly submerging their own individual identities in the collective identity of the walking city. A similar 
mixture of horror and sublimity permeates the conclusion of Barker's novel Imajica, where the travelers who have reached the City of God realize that it is the City as God:

...his Father, for all His apparent absence, was in fact here in front of him; and to his left, and to his right, and above his head and beneath his feet. What were those gleaming folds at the windows, if they weren't skin? What were those arches if they weren't bone?... This was the City of God; and God was the city. (p. 1066)

\section{Visible Cities}

In his compendium of urban metaphors Invisible Cities, Italo Calvino writes: "Cities, like dreams, are made of desires and fears". The monstrous urban body expresses collective desires and fears that have shaped the industrial metropolis for the last hundred and fifty years: the desire for interconnectedness and the fear of losing control; the longing for community and the horror of the crowd; the sense of empathy and the distrust of strangers. Through literalization, fantasy makes visible the spatial practices that have shaped the world we live in - the world of giant, growing, vital cities, in which both light and darkness mingle to create the experience of the urban sublime.

\section{Footnotes}

[1] See Gerard Genette's Narrative Discourse (1980) on the difference between the diegetic ("story") and extradiegetic ("discourse") level of the text.

[2] See: Gomel, 2011; 2014.

[3] <http://knarf.english.upenn.edu/PShelley/pbell.html>

\section{Works Cited}

ACKROYD, Peter. London: The Biography. London: Vintage, 2000. Print.

BARKER, Clive. Imajica. New York: Harper Collins, 1991. Print.

"In the Hills, the Cities". Barker, Clive. Books of Blood, vol.1-3. New York: Berkley Books, 1990. Print.

BEAR, Greg. “'Blood Music'”. WOLHEIM, Donald. Best Science Fiction of the Year 1985. . New York: Doubleday, 1986. 1-26. Print.

BLACK, Holly. Valiant: A Modern Tale of Faerie. New York: Simon Pulse, 2006. Print. Blade Runner. Dir. Ridley Scott. 1982. Film. 
BURGIN, Victor. In/different Spaces: Place and Memory in Visual Culture. Berkeley: University of California Press., 1996. Print.

CAVALLARO, Dani. The gothic vision: three centuries of horror, terror and fear. London: Continuum, 2002. Print.

DICKENS, Charles. Bleak House. Nook Books, 2009 (1853). Electronic.

DONALD, James. Imagining the Modern City. Minneapolis: U of Minnesota Press., 1999. Print.

GAIMAN, Neil. Neverwhere. London: Penguin, 1996.

GENETTE, Gerard. Narrative Discourse. Ithaca NY: Cornell University Press, 1980. print.

GOMEL, Elana. Narrative Space and Time: Representing Impossible Topologies in Literature. New York: Routledge, 2014. Print.

“'Part of the Dreadful Thing': The Urban Chronotope of Bleak House". Partial Answers 9.2 (2011), p. 297-311. Print.

GORDON, Roderick \& WILLIAMS, Brian. Tunnels. London: Chicken House, 2007. Print.

HALE, Jonathan A. Building Ideas: An Introduction to Architectural Theory. Chichester: John Wiley and Sons Ltd., 2000. Print.

LANG, Fritz. Metropolis (screenplay). London: Lorrimer, 1973 (1927). Print.

LEBBON, Tim. Contagious. London: Pyr, 2013. Print.

. Echo City. New York: Ballantine Books, 2010.

LECORBUSIER. The Modulor: A Harmonious Measure to the Human Scale Universally Applicable to Architecture and Mechanics. Trans. Peter de Francis and Anne Bostock. London: Faber and Faber., (1951; 1961. Print.

LEFEBVRE, Henri. The Production of Space. Cambridge: Blackwell, 1998 (1974). Print. Mannolini-Winwood, Sarai. "The Origins of Urban Fantasy." n.d.

https://www.academia.edu/. Electronic. 20122015.

PALMER, Stephen. The Rat and the Serpent: a fable in black-and-white. London: infinity plus, 2004. electronic.

REEVE, Philip. A Darkling Plain. London: HarperCollins, 2006. Print. . Mortal Engines. London: Eos, 2001. Print.

SCHIVELBUSCH, Wolfgang. Disenchanted Night: The Industrialization of Light in the Nineteenth Century. Berkeley: University of California Press, 1988. Print. 
SENNETT, Richard. Flesh and Stone: The Body and the City in Western Civilization. London: W. W. Norton and Company, 1994.

SIX, Abigail Lee \& THOMPSON, Hannah. "From Hideous to Hedonist: the Changing Face of the Nineteenth-Century Monster". Mittman, Asa Simon with Peter J.Dendle. The Ashgate Research Companion to Monsters and Monstrous. Farnham, Surrey: Ashgate, 2013. 237-257. Print.

STALLYBRASS, Peter \& WHITE, Allon. The Politics and Poetics of Transgression. Ithaca: Cornell University Press, 1986. Print.

STEVENSON, Robert Louis. “Virginibus Puerisque”. 2004.eBooks@Adelaide; http://etext.library.adelaide.edu.au/s/stevenson/robert_louis/s848vi/>. Electronic. 13 October 2014.

The Dark City. Dir. Alex Proyas. 1998. Film.

The Thirteenth Floor. Dir. Josef Rusnak. 1999. Film.

TIETZ, Jurgen. The Story of Architecture of the 20th Century. Koln: Konemann., 1989. Print.

TODOROV, Tzvetan. The Fantastic: A Structural Approach to a Literary Genre. Ithaca: Cornell University Press, 1987.

TRENCH, Richard \& HILLMAN, Ellis. London Under London. London: John Murray Ltd., 1984. Print.

VENTURI, Robert, Denise Scott Brown, Steven Izenour. Learning from Las Vegas. Cambridge, Mass: MIT Press, 1977. Print.

WILLIAMS, Raymond. The Country and the City. New York: Oxford University Press, 1973. Print.

WILLIAMS, Rosalind. Notes on the Underground: An Essay on Technology, Society, and the Imagination. Cambridge, Mass.: The MIT Press, 1990. Print.

WONG, Kim-yuen. "'On the Edge of Space: Hong Kong Cityscape, Blade Runner, The Ghost in the Shell"'. Science Fiction Studies 27. March 2000: (2000): 1-21. Print.

Recebido em 29/12/2016

Aceito em 17/02/2017. 